\title{
The Failure on Our Governance: Reaksi Masyarakat Sipil terhadap Kebijakan Publik di Masa Pandemi
}

\section{Felisitas Friska Dianing Puspa ${ }^{1}$, Nicolas Kriswinara Astanujati ${ }^{2}$}

Diserahkan: 15 Oktober 2021 | Diterima: 27 Desember 2021 | Diterbitkan: 7 Januari 2022

\begin{abstract}
Abstrak
Tulisan ini berusaha memberikan elaborasi mengenai beragam faktor yang berperan dalam kegagalan kebijakan pemerintah pada masa krisis, seperti pandemi Covid-19, sehingga memunculkan reaksi dari masyarakat sipil. Kegagapan terjadi atas dasar minimnya preparedness, perbedaan sense of urgency, broken linkage, hingga rendahnya sense of belonging menjadi bahasanyang disajikan lebih lanjut dalam tulisan ini.Bagaimana pemerintah akhirnya mengakomodasi hadirnya komunitas sebagai bentuk resistensi yang mewujudkan terciptanya self-governing community. Yangmana, keberadaannya juga mendorong berjalannya suatu demokratisasi melalui skema network governance. Melihat bahwa pergerakan dan polarisasi perlawanan sipil yang semakin tumbuh menjamur sebagai bentuk gerak komunal di masa pandemi, Indonesia menjadi salah satu negara yang turut meningkatkan resistensi. Tulisan ini dikaji melalui realita lapangan serta beragam sumber sekunder seperti berita, jurnal, maupun buku. Tulisan ini menjelaskan penyebab pemerintah gagap dalam menangani pandemi hingga memicu kemunculan masyarakat sipil. Akhirnya, masyarakat
\end{abstract}

\footnotetext{
1 Penulis adalah mahasiswa program sarjana Departemen Politik dan Pemerintah Universitas Gadjah Mada. 2 Penulis adalah mahasiswa program sarjana Departemen Politik dan Pemerintah Universitas Gadjah Mada.
} 
sipil (civil society) menjadi solusi (mobilizing for action) dalam tata kelola pemerintahan (network governance).

Kata kunci: civil society, broken linkage, network governance, selfgoverning community, civil resistance.

\section{PENDAHULUAN}

Fenomena wabah Covid-19 (Coronavirus Disease 2019) berhasil menggemparkan dunia. Wabah yang telah bertransformasi menjadi pandemi ini berdampak kepada ratusan negara dengan memberikan guncangan, khususnya dalam ranah kesehatan. Fenomena tersebut menyebabkan kegamangan pemerintah di banyak negara akibat pengabaian dan ketidakmampuan menangkap informasi yang ditetapkan dalam skala global (Mas'udi \& Winanti, 2020). Alhasil, banyak negara tidak siap dalam merespons kondisi dengan lebih tanggap. Sekretaris Jenderal PBB, Antonio Gunterres menambahkan bahwa di awal pandemi Covid-19, dunia gagal merespons penanggulangan pandemi Covid-19 secara cepat. Hal ini dilatarbelakangi oleh individualitas dari negara akibat dari prioritas penanganan permasalahan dalam suatu negara harus melalui prosedur yang tersistematis mengikuti urutan prioritas yang dibuat berdasarkan jumlah konstituen yang mendukung (Ahdira, 2020). Padahal, penanganan wabah seperti Covid-19 
membutuhkan fleksibilitas agar dinamika pemahaman permasalahan dan pencarian solusinya dapat berjalan lebih mudah dan cepat.

Di Indonesia, benih pandemi Covid-19 mulai muncul pada bulan Maret 2020 (Gitiyarko, 2021). Guncangan tersebut ditandai dengan peningkatan jumlah pasien yang sangat signifikan. Berawal dari 2 pasien di awal Maret 2020 menjadi 1.528 pasien pada 31 Maret 2020 (Nugroho, 2020). Kondisi peningkatan ini akhirnya mendesak pemerintah untuk melakukan tanggapan cepat dan tepat guna menghalau laju penyebaran Covid-19. Deep Knowledge Group yang dimuat di Forbes pada 13 April 2020 memperkuat pernyataan tersebut dengan memberikan pernyataan bahwa Indonesia masuk dalam kategori 100 negara berisiko paling tinggi dalam menangani pandemi Covid-19. Lebih jauh, Indonesia menempati urutan 97 dari 100 negara (Colangelo, 2020).

Keterpurukan ekonomi, ditambah sektor kesehatan yang kolaps menjadi gambaran bahwa kebijakan yang diterapkan di Indonesia tidak tepat sasaran dalam mengatasi perebakan Covid-19 di dunia. Tata kelola pemerintah Indonesia telah menunjukkan kegagalan melalui komunikasi politik yang dilakukan pejabat publik. Hal ini ditunjukkan dengan adanya pejabat publik yang memberi pernyataan bahwa Indonesia 
akan kebal dari Covid-19 pada bulan April 2020 (Gunadha \& Rahmayunita, 2020). Narasi cerita tersebut mengantarkan kita pada persepsi bahwa antisipasi pemerintah terhadap pandemi pandemi terbilang nihil. Pun, hal ini menjadi kerangka yang memengaruhi pola gerak dan adaptasi yang dilakukan masyarakat atas persebaran pandemi Covid-19.

Akibat dari absennya grand design pemerintah Indonesia ketika menghadapi masa krisis seperti pandemi Covid-19 dan ketidaktahuan arah masyarakat, dinamika yang terjadi terfragmentasi dan mendorong setiap entitas untuk saling menyalahkan satu sama lain. Ketidakjelasan rumah sakit rujukan, absennya protokol test, minimnya ketersediaan alat test alat pelindung diri (APD), dan banyak hal lain menjadi bentuk kegagapan yang mewarnai persebaran pandemi di awal 2020 lalu (Mas'udi \& Winanti, 2020). Gagapnya antisipasi dan gagalnya koordinasi ini akhirnya menyebabkan terciptanya jarak antara pemerintah dan masyarakat serta standarisasi penanganan pandemi Covid-19 yang belum disepakati pada tataran level eksekutif maupun legislatif. Jarak yang terbentuk rupanya juga dipengaruhi oleh kepentingan aktor pada skala pusat maupun daerah, mengingat setiap aktor memiliki kepentingan yang diperjuangkan melalui kewenangannya secara 
formal. Hingga akhirnya, ego sektoral menyumbat sinergitas kebijakan yang hadir. Padahal, kebijakan yang memadai adalah kebijakan yang mampu menjamin tata kelola pemerintahan yang transparan guna mencukupi pemenuhan hak warga di situasi krisis seperti pandemi ini (Mas'udi \& Winanti, 2020).

Tindakan tanpa memikirkan sense of urgency yang dimiliki pemerintah ini justru semakin mendorong ketidakpercayaan dalam masyarakat. Padahal, koordinasi dan saling menumbuhkan rasa kepercayaan di era seperti ini menjadi kunci keberhasilan untuk keluar dari keterpurukan. Pun, beberapa kebijakan yang dihadirkan oleh pemerintah selama pandemi tampak timpang. Tidak semua kalangan dapat dengan mudah ikut serta dalam kebijakan yang sudah dibuat karena fragmentasi baru pada kelas sosial. Dengan demikian, gap yang terbentuk semakin menunjukkan perbedaan fokus kepentingan antara masyarakat dan pemerintah karena minimnya pelibatan masyarakat dalam perumusan kebijakan yang ada. Contoh fenomena yang terjadi akibat perbedaan sense of urgency tampak pada penutupan dan pembatasan tenaga kerja di beberapa lapangan kerja yang gulung tikar atau tidak mampu membayar tenaga kerjanya. 
Realita tersebut terbukti dari Pemutusan Hubungan Kerja (PHK) sebanyak 29,4\% pekerja akibat terdampak pandemi Covid-19 (Triatmojo, 2021). Belum lagi ditambah dengan penetapan Undang-Undang Cipta Kerja yang disahkan di tengah pandemi, diimana terdapat salah satu permasalahan pada kontrak kerja yang harus menyesuaikan kebutuhan perusahaan. Adanya pasal tersebut justru semakin mempermudah perusahaan untuk mengeksploitasi tenaga kerjanya, belum lagi pemenuhan hak tenaga kerja yang dikurangi dari kebijakan sebelumnya. Realita ini jelas menjadi beban bagi masyarakat yang selama ini berusaha untuk bertahan dalam situasi pandemi, khususnya pada sektor buruh maupun pekerja informal. Karena, memilih untuk mengorbankan satu sektor bukanlah hal yang mudah di era pandemi seperti ini. Mengingat bahwa individu sebagai agen memiliki dualisme antara kehidupan pekerjaan maupun kehidupan pribadi dan keluarga yang menjadi tantangan tersendiri.

Melalui beberapa hal yang telah dibahas sebelumnya, dapat terlihat bahwa komunikasi pemerintah dalam menyampaikan kondisi ke publik memang patut mendapat kritik. Kegagalan ini banyak ditunjukkan melalui blunder atau kekeliruan pemerintah ketika menyampaikan informasi (Mas'udi \& Winanti, 
2020), sehingga terjadi ketidaksinambungan dan kebingungan masyarakat dalam mengambil langkah untuk menghadapi pandemi Covid-19. Dari narasi cerita tersebut, dapat dianggap bahwa pemerintah memiliki peran vokal terhadap kegiatan yang diambil masyarakat. Tetapi, kegagalan komunikasi menjadikan pemerintah pada kegagapan sehingga menurunkan kepercayaan masyarakat kepada pemerintah. Argumentasi ini dibuktikan melalui survei Lembaga Survei Indonesia (LSI) pada periode Februari hingga Maret 2021, dimana terjadi penurunan tingkat kepercayaan publik terhadap kemampuan kepala negara menangani pandemi (Saputra, 2021).

\section{METODE PENELITIAN}

Metode penelitian yang digunakan dalam tulisan ini merupakan metode kualitatif dengan menggunakan studi kasus. Metode ini dipilih lantaran dianggap mampu menerangkan fenomena yang terjadi secara lengkap dan menyeluruh. Selain itu, metode kualitatif juga dapat memaparkan sesuatu yang tidak bisa dipahami dengan data statistik atau angka. Tulisan ini menggunakan analisis kualitatif mulai dari reduksi data, penyajian data, dan data kesimpulan. Pengumpulan data dalam tulisan ini menggunakan data primer yang 
tersaji melalui observasi lapangan dan data sekunder melalui literatur review. Karenanya, analisis data yang dilakukan penulis bersifat induktif dengan berdasarkan fakta yang ditemukan di lapangan. Studi kasus yang dipaparkan penulis sekaligus menjawab pertanyaan tentang "bagaimana kemunculan gerakan civil society sebagai respons terhadap kegagalan kebijakan publik di masa pandemi?”

\section{CIVIL SOCIETY SEBAGAI WUJUD SELF-GOVERNING COMMUNITY}

Sebagai komponen yang saling berkaitan, civil society merupakan suatu bentuk tatanan yang memiliki peran dalam menggerakkan roda pemerintahan. Secara kultural, civil society bermula dari tradisi pemikiran Barat. Di Indonesia, civil society telah membawa perubahan secara struktural pada sistem pemerintahan. Pada sisi historis, kehadirannya tidak dapat dilepaskan dari beberapa peristiwa, seperti kemerdekaan Indonesia maupun runtuhnya rezim Orde Baru. Larry Diamond membawa gagasan bahwa civil society hadir sebagai wujud dari implementasi demokrasi (Diamond, 1994). Oleh karena itu, indikator pertumbuhan demokrasi di Indonesia salah satunya adalah tumbuh dan lahirnya civil society. 
Thomas Aquinas dengan konsep negara kota turut memperlihatkan bahwa kelahiran commonwealth bermula dari civil society atau political society (Smelser, 1962). Sementara, Hyden menegaskan bahwa civil society adalah arena tempat asosiasi-asosiasi berkompetisi untuk memengaruhi dalam interaksinya dengan negara atau organisasi-organisasi antar pemerintah dan sekaligus adalah agen pada dirinya sendiri (Suharko, 2005). Pun, Delanty (2018) memiliki pemahaman unik dimana "community is not an underlying reality, but is constructed in actual processes of mobilization".

Moralitas atau status sosial yang tidak diprioritaskan mampumenjadimotivasi utama bergeraknya civilsociety. Konsep yang ada telah menunjukkan bahwa civil society menjadi aspek penting dalam membawa perubahan dan perkembangan bagi sebuah negara. Namun, perlu penekanan bahwa tidak ada masyarakat yang bisa eksis tanpa kehadiran negara. Karenanya, pergerakan yang dilakukan civil society pada situasi pandemi didasari oleh keinginan mereka bertahan hidup. Pergerakan ini juga dilatarbelakangi oleh ketidakmampuan pemerintah menyediakan apa yang dibutuhkan masyarakat sehingga secara mendesak, masyarakat bergerak dengan prinsip komunal untuk menopang kebutuhan mereka, atau dapat dikatakan bahwa masyarakat mewujudkan self- 
governing community. Melihat hal tersebut, civil society bisa dikatakan sebagai agen kunci dalam setiap proses demokratisasi (Suharko, 2005).

Civil society mampu meningkatkan demokrasi ketika ia mampu menciptakan ruang publik dalam masyarakat. Namun, pengedepanan civil society sebagai agen demokrasi secara berlebih juga bisa menciptakan suatu kerentanan bagi demokrasi sendiri. Civil society menempati peran sebagai pembangun sekaligus perusak demokrasi (Hadiwinata, 2005). Oleh karenanya, dibutuhkan sense of belonging, saling mengisi antara pemerintah dan masyarakat dalam melaksanakan tata pemerintahan yang baik. Kedua belah pihak harus memiliki sense of urgency yang sejalan atau paling tidak memiliki indikator capaian yang sama. Apalagi, jika demokrasi ingin mencapai tahap konsolidasi yang baik, pemaksaan dan kekerasan harus dibatasi seminimal mungkin (Hadiwinata, 2005). Karenanya, apabila perbedaan ideologis masyarakat dan pemerintah tidak segera menemukan titik temu, kekacauan atau konflik hanya akan terjadi secara berkepanjangan dan menuju pada kerusakan tatanan pemerintahan.

Lebih jauh, konsep pemikiran mengenai civil society dan negara telah dipertegas oleh Hegel, dimana ia memandang bahwa civil society dan negara 
bukan hanya dua entitas yang berbeda, melainkan dua entitas yang berlawan juga (Jb \& Darmawan, 2016). Meski begitu, civil society acap kali diintegrasikan dalam negara sebagai institusi yang menyesuaikan geraknya dengan negara. Hal ini terjadi lantaran civil society tidak bisa dibiarkan berjalan tanpa kontrol. Karenanya, ia masih membutuhkan negara sebagai instansi besar dalam memberikan kontrol atas ruang geraknya di negara. Namun, karena civil society hadir karena kegagalan negara atau broken linkage, mereka sering kali merasa tidak membutuhkan peran negara sebagai pemberi kontrol atas ruang gerak mereka. Hal ini disebut dengan defisit kepercayaan masyarakat akan lembaga publik (Lay \& Ambardi, 2014). Pemikiran inilah yang menyebabkan lahirnya miskonsepsi atas ruang gerak atau eksistensi antara civil society dan negara. Fenomena tersebut sering kali dinilai salah kaprah karena menciptakan self-governing community, alihalih menguatkan hubungan dalam network governance.

Weapon of the weak milik Antonio Gramsci (Etzioni-Halevy, 2011) menjadi hal yang dapat menggambarkan bagaimana civil society hadir menjadi senjata masyarakat dalam mempertahankan dan memperjuangkan hak-haknya. Civil society disinyalir menjadi gerakan kolektif yang hadir karena adanya 
broken linkage atau kondisi dimana negara tidak mampu memenuhi kebutuhan warganya,-sehingga dengan keterpurukannya, masyarakat cenderung bergabung untuk memperjuangkan hal yang mereka butuhkan. Pun, dalam negara demokratis, masyarakat sipil menjadi penggerak negara yang lebih kuat dari suatu konstitusi. Ia telah menjadi penggerak utama, kunci berjalannya demokrasi. Tanpa kehadiran civil society, demokrasi tidak akan dapat dipertahankan dalam waktu lama. Namun, dengan adanya konsepsi ini, apakah civil society mampu memegang perannya dalam meningkatkan demokrasi? Atau apakah kehadirannya justru menghambat terjadinya konsolidasi demokrasi?

Banyak wacana hadir sebagai pendorong konsepsi kehadiran civil society sebagai elemen penting demokrasi. Kehadirannya merupakan gerakan nyata dalam merespons kegagalan negara dalam memenuhi kebutuhan warganya. Dapat dikatakan bahwa civil society adalah agen atau aktor dan arena. Dikatakan sebagai arena karena civil society memiliki pola interaksi saling memengaruhi untuk mencapai tujuan kelompoknya. Oleh karena itu, masifnya gerakan kolektif yang dilakukan civil society pada gilirannya menjadi validasi berjalannya proses demokratisasi. Pun, gerakan ini akhirnya menjadi gerakan kolektif sebagai 
modal perekat yang mengikat masyarakat secara bebas, tidak terikat, dan tidak merebutkan suatu kedudukan tertentu. Philippe Schmitter menambahkan bahwa pergerakan civil society harus mengemban empat nilai, yakni otonomi, aksi kolektif, tidak merebutkan kekuasaan, dan tunduk pada hukum yang berlaku (Hadiwinata, 2005).

Pelabelan kegiatan civil society ke dalam gerakan kolektif ini mengingatkan pada teori collective behavior milik Neil J. Smelser (1965), dimana gerakan kolektif hadir dalam wujud spontanitas dan berubahubah. Roger Brown dalam buku milik Smelser (1965) menjelaskan lebih dalam bahwa terdapat dimensi dalam pengklasifikasian kolektivitas. Pengklasifikasian ini meliputi: arena yang digunakan untuk berkumpul (dalam melakukan gerakan kolektif), frekuensi dan polarisasi anggota kelompok kolektif, serta adanya kelanggengan antar anggota kelompok Oleh karenanya, komunikasi dan interaksi dapat dikatakan sebagai karakteristik kunci dari teori collective behavior. Teori ini dapat dikatakan sesuai dengan pola gerakan civil society yang muncul berdasar kondisi yang terjadi (fleksibel), sesuai tuntutan yang hadir, dan bukan menjadi satu hal yang pakem atau kaku. 
Oleh karenanya, dapat dipahami bahwa civil society sebagai gerakan kolektif merupakan mobilisasi atas tindakan sosial untuk menciptakan tatanan baru. Hal ini turut diperkuat dengan rasa empati, sama rasa yang digunakan untuk dasar pergerakan secara kolektif. Sayangnya, kemunculan gerakan kolektif yang didasari pemenuhan broken linkage ini sering kali malah memengaruhi kepercayaan masyarakat atau publik terhadap kedudukan pejabat publik. Semakin tingginya kekecewaan atas negara dan menurunnya kepercayaan masyarakat terhadap pengelola pemerintahan menjadi pendorong lahirnya tata gerakan kolektif yang baru dan menjamur dalam masyarakat.

Pernyataan tersebut diperkuat oleh konsepsi Putnam, dimana gerakan masyarakat sipil mampu mendorong terbentuknya modal sosial. Yang dalam pelaksanaannya, modal sosial memiliki tiga bentuk yang berbeda, yaitu social trust $^{3}$, social norms ${ }^{4}$, dan civic management ${ }^{5}$ (Putnam, 1993). Salah satu komponen yang menarik untuk dibahas dan berkaitan dengan gerakan kolektif

3 Harapan yang tumbuh dalam suatu masyarakat yang ditunjukkan oleh adanya perilaku jujur, teratur, dan kerja sama berdasarkan norma-norma yang dianut bersama.

4 Pemahaman, nilai, harapan, dan tujuan yang diyakini dan dijalankan bersama oleh sekelompok orang.

5 Jaringan-jaringan kerja sama antar manusia terwujud dari infrastruktur dinamis dari modal sosial yang memfasilitasi terjadinya komunikasi dan interaksi yang memungkinkan tumbuhnya kepercayaan dan memperkuat kerja sama. 
masyarakat adalah social trust atau tingkat kepercayaan sosial masyarakat.

Melalui kajian Putnam mengenai social trust, secara tidak langsung konsep tersebut berkaitan dengan artikulasi kepentingan dan agregasi kepentingan publik oleh lembaga pemerintahan. LSI sendiri telah memperlihatkan bahwa kepercayaan masyarakat terhadap legislator (DPR) hanya sebesar 71\% (peringkat 2 terbawah) dan terhadap pemerintah pusat hanya sebesar 85\% (Putri, 2021). Akhirnya, angka ini akan memengaruhi hubungan kausalitas antara masyarakat (civil society) dan pemerintah yang ditunjukkan dari rendahnya kepercayaan masyarakat terhadap pemerintah.

Sebenarnya, hubungan kausalitas tidak serta merta hadir karena kegagalan pemerintah dalam memenuhi kebutuhan masyarakat. Tetapi, kondisi ini juga dipengaruhi oleh konstruksi serta pola perilaku yang terjadi secara kontinu dalam masyarakat. Sayangnya, kontinuitas yang tidak tentu turut memengaruhi social trust yang terbangun di masyarakat. Salah satu hal yang menjadikan rendahnya social trust adalah konstruksi bahwa negara telah gagal memenuhi kebutuhan masyarakat (Putnam, 1993). Maka masyarakat memunculkan gerakan kolektif secara mandiri untuk 
memenuhi kegagalan atau broken linkage yang tercipta. Pasalnya, realita ini malah tertanam menjadi konstruksi sosial dan menciptakan gap pemisah antara pemerintah dan masyarakat. Fenomena gap pemisah inilah yang menjadi poin pembahasan lebih jauh dalam tulisan ini.

Pembahasan tersebut menunjukkan bahwa civil society atau masyarakat sipil merupakan bentuk perpanjangan tangan dari negara. Perpanjangan tangan di sini adalah penanda bahwa meski bertolak belakang, negara dan masyarakat menjadi entitas yang tidak dapat dipisahkan. Selain itu, keberhasilan pergerakan kedua entitas tersebut memerlukan sense of belonging serta sense of urgency yang sama. Kehadiran civil society sebagai penyambung broken linkage menjadi penguat paradigma network governance yang juga memerlukan keterlibatan masyarakat sipil. Maka, civil society mampu hadir sebagai pembawa pengaruh penting bagi kehadiran sebuah negara, terutama sebagai gerakan spontan dalam mengisi absennya pemerintah pada masa krisis. Oleh karenanya, penempatan civil society dalam tulisan ini dapat dikatakan menjadi satu komponen dalam berjalannya network governance. Singkatnya, civil society merupakan bagian dari network governance. 


\section{FRAMEWORK NETWORK GOVERNANCE}

Menurut Osborne (2010), network governance merupakan pengorganisasian pemerintahan secara otomatis pada jaringan antar organisasi dengan atau tanpa campur tangan pemerintah. Lebih lanjut, Provan dan Kennis (2008) melihat bahwa pengelolaan governance tidak hanya bertumpu pada salah satu organisasi, tetapi pada fungsionalisasi antar organisasi guna mengumpulkan informasi atau sumber daya untuk memecahkan permasalahan bersama atau yang dapat disebut sebagai collective action. Sudut pandang ini digunakan untuk melihat bahwa permasalahan jaringan (network) tidak terlepas dari permasalahan efektivitas yang telah merusak motivasi untuk melakukan gerakan kolektif. Oleh karenanya, diperlukan mekanisme koordinasi yang dapat menyinambungkan tujuan setiap organisasi dalam merespons suatu permasalahan di masyarakat. Kebutuhan akan hal tersebut, utamanya tercantum dalam beberapa format network governance yang dalam tulisan secara khusus membahas participantgoverned networks (Provan \& Kennis, 2008).

Sederhananya, participant-governed networks mencoba untuk menggambarkan bahwa partisipasi dalam jaringan dapat berjalan dengan atau tanpa upaya koordinasi dari organisasi utama (pemerintah 
pusat) yang memiliki kewenangan dan pengaruh besar terhadap keberhasilan jaringan. Keberhasilan tersebut terwujud dalam pengelolaan jaringan yang berbasis desentralisasi dan mengikutsertakan seluruh bagian dari jaringan yang memiliki hubungan dengan proses yang dilakukan oleh tata kelola pemerintahan (Provan \& Kenis, 2008). Desentralisasi yang dimaksud merupakan pola komunikasi simetris dan asimetris antara satu organisasi dengan organisasi lainnya. Misalnya jaringan pemerintah daerah terhadap pemerintah daerah lainnya atau pemerintah daerah dengan komunitas. Begitu juga sebaliknya, kolaborasi tersebut terjadi agar governance dapat berjalan lebih efisien mengikuti kebutuhan administratif yang diperlukan dalam keikutsertaan anggota organisasi pada jaringan. 


\section{Figur 1. Bagan Self-Governed Network}

\section{Self-Governed Network}

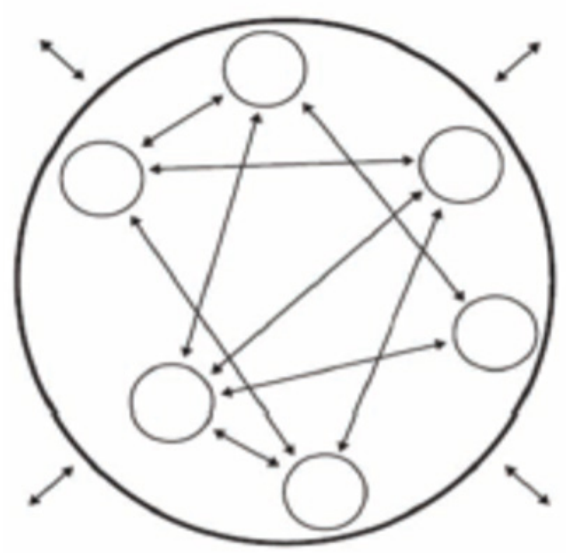

\section{Network members that are collectively involved in network governance \\ $\longrightarrow$ Stronger relationship \\ $\ldots \rightarrow$ Weaker relationship}

(Provan \& Kenis, 2007; Popp et.al., 2015; Greany \& Higham, 2018)

Participant-governed networks yang juga dikenal sebagai shared network atau self-governed network memiliki hubungan antar organsiasi yang erat. Hal tersebut dijelaskan melalui figur 1, dimana setiap entitas di dalam jaringan mengonsolidasikan dirinya sebelum keluar dari jaringan utamanya. Format network governance ini berisikan jumlah organisasi yang tidak banyak dan karena itu, aspek seperti tujuan jaringan dapat secara khusus terlaksana karena konsensus yang 
tinggi. Sebagaimana yang diketahui dalam pembahasan mengenai civil society sebelumnya, sense of belonging yang dimiliki civil society membentuk apa yang menjadi kebutuhan bersama dalam jaringan. Berdasarkan hal itu, maka gerak civil society sebagai reaksi terhadap adanya kegagalan kebijakan publik dalam arena jaringan di luar lingkupnya dapat dipetakan, sebagaimana dalam figur 1, organisasi civil society berdampak dan menjalin relasi secara erat dalam sektor internal maupun eksternal jaringan.

\section{CIVIL SOCIETY SEBAGAI BENTUK REPRESENTASI DALAM KONSEP NETWORK GOVERNANCE}

Berdasarkan pembahasan terkait network governance dan kemunculan civil society di masa pandemi, dapat dilihat bahwa terdapat garis yang menunjukkan dorongan kuat dari civil society untuk menjawab permasalahan jaringan yang dimiliki oleh pemerintah. Permasalahan networking ini menunjukkan bahwa informasi yang diberikan oleh pemerintah di awal pandemi cenderung sentralistik. Dengan kondisi tersebut, ruang partisipasi masyarakat dapat lebih terbuka dan demokrasi yang terjadi dapat diimplementasikan sesuai dengan semangat yang 
mengakar di masyarakat. Keberadaan civil society di sini, tidak semata sebagai pendorong tata kelola jaringan, tetapi juga pemberi keluasan data dan informasi untuk efektivitas penanganan pandemi yang selama ini dilihat sebagai permasalahan kolektif atau bagian dari collective goods problem. Oleh karenanya, sektor-sektor yang tidak secara langsung dilihat oleh pemerintah dapat tetap tersentuh oleh kehadiran masyarakat sendiri.

Keterkaitan antara network governance dan civil society akhirnya sampai pada kerangka berpikir bahwa satu komponen dalam governance dan lainnya bergerak secara tarik-menarik. Meski begitu, civil society merupakan variabel dependent dalam kerangka pikir ini. Hal ini dikarenakan berjalannya network governance membutuhkan peran serta civil society sebagai penggerak representasi demokratis di dalamnya. Fenomena tersebut diperkuat Sorensen (2014) melalui tulisannya dalam Democratic Theory and Network Governance bahwa sistem tata kelola jaringan pemerintahan didasarkan pada keberadaan tatanan masyarakat sebagai penggerak demokrasi. Penciptaan rasa komunal yang terbentuk dalam pelaksanaan demokratisasi merupakan inti berdiri dan berjalannya network governance. Tanpa rakyat tidak mungkin ada perwakilan, dan tanpa adanya perwakilan 
maka representasi rakyat dalam tatanan pemerintahan tidak berjalan sesuai dengan identitas kolektif yang merupakan gagasan dasar dari network governance (Sorensen, 2014).

\section{CASE STUDY: KEMUNCULAN CIVIL SOCIETY SEBAGAI REAKSI KEGAGALAN NETWORK GOVERNANCE DI MASA PANDEMI}

Selama pandemi masih berlangsung, terhitung semenjak Maret 2020 sampai dengan Oktober 2021 dan terus berlanjut, berbagai bentuk transformasi pada civil society mengakar luas dan berkembang pesat. Mulai dari gerakan jaga warga dengan saling topang pemenuhan kebutuhan sehari-hari (penyediaan sayur atau bahan makanan) di masyarakat, hingga open donasi, dan inisiatif pembukaan relawan hadir dalam pengembalian kestabilan masyarakat di masa pandemi. Seperti pelaksanaan “jogo tonggo", program Pemerintah Provinsi Jawa Tengah yang dijalankan dengan maksud menjaga dan memantau kondisi antar tetangga (Risan, 2021). Gagasan kehadiran dan pergerakan civil society seperti pelaksanaan "jogo tonggo" bukan merupakan wacana baru lagi. 
Dengan sadar, masyarakat bergerak bersamasama dengan menjadikan solidaritas sebagai pilar fundamental dalam memenuhi apa yang tidak bisa dipenuhi oleh pemerintah. Fenomena ini dikuatkan oleh konsepsi Hobbes bahwa civil society bukan berarti masyarakat menciptakan negara, melainkan kedua pilar tersebut hadir melalui kontrak sosial yang disatukan di bawah kekuasaan negara (Jb \& Darmawan, 2016). Atau dalam hal lain, civil society dipahami sebagai pergerakan atas bentuk kemandirian aktivitas yang berdampingan dengan negara, bersama melalui konsep "social contract". Social contract di sini berarti bahwa sumber kekuasaan pemerintah berasal dari masyarakat, pemerintah sebagai pelaksana mandat, penjamin kestabilan masyarakat.

Di tengah terbatasnya segala fasilitas yang dimiliki pemerintah dalam pemenuhan kebutuhan masyarakatnya, "rakyat bantu rakyat" muncul sebagai contoh gerak kolaborasi nyata yang tidak sebatas narasi. Banyaknya ranah bantuan yang ditawarkan masyarakat untuk masyarakat sendiri menggambarkan solidaritas tanpa batas. Tanpa memperhitungkan balasan atau urgensi politik lain, masyarakat cenderung bergerak secara spontan ketika kelompoknya mengalami kekurangan atau membutuhkan bantuan. Meski tidak 
mengeluarkan dari keterpurukan ekonomi, gerak "rakyat bantu rakyat" menjadikan banyak pihak merdeka dari kelaparan. Gerak seperti inilah yang tidak biasa dibawa pemerintah dan menjadi indikator khusus kemunculan civil society. Gerak saling bantu ini menjadikan pilihan hidup berdaulat atas pangan sebagai suatu kewajiban yang harus diisi masyarakat secara bersama. Wujud solidaritas ini merupakan manifestasi swadaya warga dan relawan yang memberi gambaran definisi sesungguhnya dari rakyat, oleh rakyat, dan untuk rakyat.

Salah satu implementasi gerakan "rakyat bantu rakyat" ini adalah kehadiran dapur umum di berbagai wilayah. Yogyakarta khususnya, menjadi pusat kemunculan jenis pergerakan civil society ini. Penyediaan makanan untuk buruh gendong menjadi salah satu bentuk program pelaksanaan "rakyat bantu rakyat" di Yogyakarta (Pangaribowo, 2020). Keberadaannya sudah berkembang melalui jaringan Solidaritas Pangan Jogja yang di dalamnya meliputi beberapa universitas dan organisasi masyarakat, seperti Universitas Gadjah Mada (UGM), Universitas Muhammadiyah Yogyakarta (UMY), Universitas Islam Indonesia (UII), hingga aktivis lingkungan dari Wahana Lingkungan Hidup Indonesia (WALHI). Pembentukan solidaritas ini bertujuan untuk membangun resiliensi 
dalam memetakan dan memecahkan persoalan pangan di Yogyakarta. Target utamanya, pekerja informal yang terdampak pandemi, seperti tukang becak, pedagang jalanan, maupun buruh gendong di pasar. Secara bertahap, nasi bungkus yang diberikan terus bertambah, berawal dari 50 bungkus hingga menjadi 100 bungkus setelah beberapa hari berjalan. Hal tersebut membuat para relawan dapur kewalahan dan tidak mampu untuk mengatasi permintaan yang meningkat (Nadia, 2021). Alhasil, beberapa dapur harus tutup karena pengorganisasiannya yang kurang terstruktur dan tersistematis.

Beranjak dari pengalaman tersebut, beberapa relawan yang pernah belajar di dapur SPJ mencoba untuk membuat bentuk komunitas yang serupa. Salah satunya, Dapur Umum Buruh Gendong yang saat ini berhasil mempertahankan strukturnya selama kurang lebih satu tahun lamanya. Dengan fokus untuk membangun solidaritas pada salah satu kelompok masyarakat saja, hubungan timbal balik antara kelompok dapur umum dan kelompok buruh gendong dapat berjalan lebih efisien. Hal tersebut menjadi solusi atas pembelajaran dari manajemen dapur SPJ yang secara acak memilih subjek sehingga tidak memiliki kesiapan menghadapi risiko permintaan yang bertambah. Selain aktivitas 
pemberian makan siang pada kelompok buruh gendong, kelompok Dapur Umum Buruh Gendong juga secara intensif memberikan layanan advokasi dan kebutuhan umum lainnya, seperti penyediaan kebutuhan toilet umum gratis di Pasar Beringharjo atau paket sembako di hari raya. Tidak jarang, komunikasi dengan pemerintah daerah dan beberapa komunitas solidaritas dalam bentuk lainnya dilakukan untuk mempertahankan eksistensi buruh gendong di pasar-pasar Yogyakarta.

\section{CIVIL SOCIETY SEBAGAI PENDORONGAN PERUBAHAN DAN SOLUSI TERHADAP PERKEMBANGAN NETWORK GOVERNANCE}

Berdasarkan pengalaman Dapur Umum Buruh Gendong di Yogyakarta dengan memberikan dampak terhadap komunitas buruhgendong dan komunitas dapur umum yang serupa menunjukkan bahwa pengalaman pengelolaan jaringan memerlukan pengelolaan yang tersistematis. Fenomena ini membawa pada kerangka pergerakan civil resistance. Dalam perkembangan zaman, gerakan masyarakat sebagai protes terbagi atas dua cara besar, yaitu civil resistance atau perlawanan sipil dan civil disobedience atau pembangkangan sipil (Chenoweth \& Cunningham, 2013; Setyawan, 2003). Civil resistance merupakan sebuah penentangan yang 
juga mencakup tindakan non-kekerasan terhadap kebijakan pemerintah. Civil resistance juga bisa dilihat sebagai sekumpulan taktik untuk mengganggu proses politik dan sosial ekonomi melalui disrupsi tanpa kekerasan. Perlawanan seperti ini biasa kita temui dalam gerakan sosial (Ma \& Cheng, 2019).

Melihat bahwa pergerakan dan polarisasi civil resistance yang semakin tumbuh saat ini, Indonesia menjadi salah satu negara yang turut meningkatkan perlawanan. Gambaran metode yang digunakan Indonesia ini kemudian sangat berfungsi secara efektif dalam menggerakkan perlawanan, selain mampu memengaruhi pergerakan sipil, metode pergerakannya pun juga mendapatkan atensi pemerintah. Kehadiran civil society sebagai gerakan komunal dalam pemenuhan apa yang tidak bisa didapat masyarakat dari negara akhirnya menjadi sebuah pertahanan atau bahkan perlawanan yang dilakukan masyarakat.

Perlawanan dalam hal ini bukan menjadi perlawanan anti negara, melainkan civil resistance dalam memperjuangkan hak, kebebasan, dan keadilan masyarakat tanpa menggunakan kekerasan (Chenoweth \& Stephan, 2011). Pengklasifikasian gerakan civil society di masa pandemi sebagai civil resistance ini dikarenakan gerak mereka dalam memperjuangkan hak 
dan kebutuhan dengan cara saling menopang satu sama lain. Pun, gerakan yang terjadi belakangan ini telah mendorong tatanan perubahan sosial dan mobilisasi di masyarakat. Maka, civil society dapat dikatakan sebagai bentuk civil resistance pada tahapan ini. Selain itu, gerakan perlawanan di masyarakat tumbuh kuat karena mereka menawarkan gerakan secara lebih bebas dengan sistem yang lebih dapat diterima karena memiliki latar belakang nasib yang sama.

Menurut International Center on Nonviolent Conflict (2011), civil resistance memiliki tiga asas kunci keberhasilan pergerakan, yaitu persatuan, perencanaan, dan disiplin tanpa kekerasan. Pencapaian atas tiga asas tersebut diperkuat dengan adanya tujuan sama yang hendak dicapai dengan melibatkan komitmen bersama. Penguatan yang terjadi secara berangsurangsur menunjukkan bahwa civil society memiliki lingkup gerak komunal secara mandiri sehingga gerakan masyarakat sipil ini dapat dikatakan bisa menjadi pengisi hilangnya kepercayaan masyarakat terhadap kehadiran negara. Meski tidak selalu menunjukkan keberhasilan, kehadiran civil society telah mengakomodasi broken linkage yang hadir antara masyarakat dan pemerintah dalam pemenuhan kebutuhan masyarakat. 
Melalui basis teori ini, pergerakan civil society sebagai civil resistance yang tergambar melalui "rakyat bantu rakyat" dan dapur umum buruh gendong perempuan terjadi karena mamiliki kesamaan tujuan, yaitu pemenuhan kebutuhan bersama. Seperti asas resistensi yang dibawa, pergerakan civil society ini mengedepankan persatuan dengan perencanaan dan disiplin kerja yang panjang. Karena pelaksanaannya dimulai dari lingkup terkecil, kelompok seperti ini memiliki sense of urgency serta sense of belonging yang sama dan cukup besar. Pun dengan solidaritas yang terbentuk di antara kelompok mereka. Dengan ini, dapat dikatakan bahwa civil resistance tidak selalu mengarah pada hal yang merusak, tetapi juga membangun tatanan sosial masyarakat yang lebih baik lagi. Dengan prinsip solidaritas dan dasar fundamental yang baik, mereka mampu memperjuangkan hak dan kebutuhan dengan terstruktur.

\section{KESIMPULAN}

Melalui landskap pandemi, hasil tulisan ini menunjukkan bahwa gerakan civil society menjadi aspek penting dalam membawa perubahan dan perkembangan bagi sebuah negara. Sebagai suatu weapon of the weak, civil society mampu memberi sentilan kuat dalam 
memobilisasi demokrasi. Seperti yang dikemukakan Delanty (2018), community is not an underlying reality, but is constructed in actual processes of mobilization. Bukan sebagai entitas terpisah, melainkan bersinergi saling mengisi dalam mewujudkan suatu network governance yang baik dengan melihat beberapa faktor seperti kepercayaan, jumlah partisipasi dalam jaringan, tujuan atau konsensus, dan keinginan untuk mencapai nilai kompentensi yang dituju (Provan \& Kennis, 2018). Melalui pendekatan collective behavior, didapati bahwa gerakan kolektif hadir dalam wujud spontanitas dan berubah-ubah. Hal ini sangat sesuai dengan karakteristik kunci dari teori collective behavior, yakni komunikasi atau interaksi. Dengan karakteristik komunikasi dan interaksi, masyarakat sipil menjadi kelompok pelaksana kekosongan ruang dalam berinteraksi dan mencukupi kebutuhan masyarakat secara komunal. Bentuk ini yang dapat menjadi contoh kepada dorongan terhadap pembaharuan dalam network governance, dimana setiap organisasi termasuk pemerintah dan masyarakat sipil berkolaborasi dan membangun arena sumber daya informasi. 


\section{REFERENSI}

\section{Buku}

Chenoweth, E. \& M. J. Stephan (2011). Why Civil Resistance Works: The Strategic Logic of Nonviolent Conflict. B. Hoffman (ed.). New York: Columbia University Press.

Delanty, G. (2018). Community, Third Edit. P. Hamilton (ed.). New York: Routledge.

Etzioni-Halevy, E. (2011). Demokrasi \& Birokrasi: Sebuah Dilema Politik. S. Malian (ed.). Yogyakarta: Total Media.

Greany, T. \& R. Higham (2018). Hierarchy , Markets, and Networks (First Edit). London: UCL Institute of Education Press.

Lay, C., \& D. Ambardi (2014). Public Distrust di Indonesia. Yogyakarta: Faculty of Social and Political Sciences, University of Gadjah Mada.

Ma, N. \& E. W. Cheng (2019). Introduction: Civil Resistance and Contentious Space in Hong Kong. 11-23. Amsterdam: Amsterdam University Press

Mas'udi, W. \& P. S. Winanti (2020). Tata Kelola Penaganan COVID-19: Kajian Awal. w. Mas'udi \& P. S. Winanti (eds.). Yogyakarta: Gadjah Mada University Press. 
Nadia, I. F. (2021). Dari Solidaritas Pangan ke Gerakan Sosial: Tidak Sekadar Membangun Resiliensi. L. Hakim, F. A. Djalong, \& M. Mas'oed (eds.). Yogyakarta: Gadjah Mada University Press.

Osborne, S. P. (2011). The New Public Governance? Emerging Perspectives on The Theory and Practice of Public Governance. S. P. Osborne (ed.). New York: Routledge.

Popp, J., B. Milward, G. Mackean, A. Casebeer, \& R. Lindstrom (2014). Interorganizational Networks: A review of the Literature to Inform Practice. Washington D.C: IBM Center for the Business of Government.

Putnam, R. D. (1993). Making Democracy Work: Civic Traditions in Modern Italy. In R. Leonardi \& R. Y. Nonetti (Eds.), New Jersey: Princeton University Press.

Smelser, N. J. (1962). Theory of Collective Behavior. New York: The Free Pass.

Suryani, N. L. (2020). Covid-19 dan New Norma(L). M. Farida (ed.). Banten: Desanta Muliavisitama. 


\section{Jurnal}

Chenoweth, E., \& K. G. Cunningham (2013). “Understanding Nonviolent Resistance An introduction." Journal of Peace Research, 50 (3), 271-276.

Darmawan \& M. C. Jb (2016). "Wacana Civil Society (Masyarakat Madani) di Indonesia." Sosiologi Reflektif, 10 (2), 35-64.

Diamond, L. (1994). "Rethinking Civil Society: Toward Democratic Consolidation." Journal of Democracy, 5 (3), 4-17.

Hadiwinata, B. S. (2005). "Civil Society: Pembangun dan Sekaligus Perusak Demokrasi.” Jurnal Ilmu Sosial dan Ilmu Politik, 9 (1), 1-22.

Murdoch, J. \& S. Abram (1998). "Defining the Limits of Community Governance.” Journal of Rural Studies, 14 (1), 41-50.

Provan, K. G. \& P. Kenis (2008). "Modes of Network Governance: Structure, Management, and Effectiveness." Journal of Public Administration Research and Theory, 18 (2), 229-252

Rhodes, R. A. W. (1996). “The New Governance: Governing without Government.” Political Studies, XLIV, 652667. 
Setyawan, Y. (2003). "Pembangkangan Sipil (Civil Disobedience) Suatu Gejala Hukum.” Jurnal Dialektika, 2 (7), 1-14

Suharko. (2005). Masyarakat Sipil, Modal Sosial, dan Tata Pemerintahan yang Demokratis. Jurnal Ilmu Sosial Dan Ilmu Politik, 8 (3), 263-29o

Susanto, D., D. A. Yusuf, \& Y. Rachmawati (2014). "Pengaruh Good Governance Terhadap Kualitas Pemberian Layanan Publik.” Jurnal Paradigma, 12 (2).

\section{Dokumen Tambahan}

Ahdira, A. (2020). "Beri Pendapat Soal Penanganan Covid-19, Sekjen PBB: Dunia Telah Gagal Hadapi Pandemi!" Pikiran Rakyat. Retrieved from https:// www.pikiran rakyat.com/internasional/pr-01850193/ beri-pendapat-soal-penanganan-covid-19-sekjenpbb-dunia-telah-gagal-hadapi-pandemi.

Colangelo, M. (2020). "Deep Analysis of Global Pandemic Data Reveals Important Insights." Forbes. Retrieved from https://www.forbes.com/sites/ cognitiveworld/2020/04/13/ covid-19-complexitydemands-sophisticated-analytics-deep-analysisof-global-pandemic-data-reveals-importantinsights/?sh=203obcd52f6e. 
Gitiyarko, V. (2021). "PSBB Hingga PPKM, Kebijakan Pemerintah Menekan Laju Penularan COVID-19." Kompaspedia.kompas.id. Retrieved from https:// kompaspedia.kompas.id /baca/paparan-topik/psbbhingga-ppkm-kebijakan-pemerintah-menekan-lajupenularan-covid-19.

Gunadha, R. \& H. Rahmayunita (2020). "8 Klaim Kontroversial Pejabat soal Corona: Promo Tiket hingga Nasi Kucing." Suara.com. Retrieved from https:// www.suara.com/news/2020/o3/16/112007/8-klaimkontroversial-pejabat-soal-corona-promo-tikethingga-nasi-kucing?page $=$ all .

International Center on Nonviolent Conflict. (2011). "Civil Resistance: A First Look." Nonviolent-conflict.org. Retrieved from https://www.nonviolent-conflict.org/ wp-content/uploads/2017/10/Civil-Resistance-AFirst-Look-Bahasa-Indonesia.pdf.

Nugroho, R. S. (2020). "Rekap Kasus Corona Indonesia Selama Maret dan Prediksi di Bulan April.” Kompas. com. Retrieved from https://www.kompas.com/tren/ read/ 2020/03/31/213418865/rekap-kasus-coronaindonesia-selama-maret-dan-prediksi-di-bulanapril?page $=$ all . 
Putri, B. U. (2021). Survei LSI Soal Kepercayaan Publik: DPR dan Parpol Urutan Paling Buncit. Retreived from https://nasional.tempo.co/read/1435647/survei-lsisoal-kepercayaan-publik-dpr-dan-parpol-urutanpaling-buncit

Risan, P. R. (2021, Juni 16). "PPKM dan 'Jogo Tonggo' Menghadapi COVID-19." Antaranews.com. Retrieved from: https://www.antaranews.com/berita/2214078/ ppkm-dan-jogo-tonggo-menghadapi-covid-19.

Saputra, M. G. (2021). "Kepercayaan Publik pada Pemerintah, Antara Data Jokowi dan Versi Lembaga Survei." Merdeka.com. Retrieved from https://www. merdeka.com/politik/ kepercayaan-publik-padapemerintah-antara-klaim-jokowi-dan-versi-lembagasurvei. Html.

Triatmojo, D. (2021). "Kemnaker: 29,4 Juta Pekerja Terdampak Pandemi Covid-19, di-PHK Hingga Dirumahkan.” Tribunnews. Retrieved from https:// www.tribunnews.com/ bisnis/2021/03/27/ kemnaker-294-juta-pekerja-terdampak-pandemicovid-19-di-phk-hingga-dirumahkan. 